\title{
Institutional Environment and Green Economic Growth in China
}

\author{
Xiaoxiao Zhou $\mathbb{D}^{1}{ }^{1}$ Lu Wang, ${ }^{1}$ and Juntao Du $\mathbb{D}^{2}$ \\ ${ }^{1}$ School of Finance, Anhui University of Finance and Economics, Bengbu 233030, China \\ ${ }^{2}$ School of Statistics, Dongbei University of Finance and Economics, Dalian 116025, China \\ Correspondence should be addressed to Juntao Du; dujuntaohope@163.com
}

Received 11 November 2020; Revised 11 December 2020; Accepted 30 December 2020; Published 9 January 2021

Academic Editor: Wei Zhang

Copyright ( 2021 Xiaoxiao Zhou et al. This is an open access article distributed under the Creative Commons Attribution License, which permits unrestricted use, distribution, and reproduction in any medium, provided the original work is properly cited.

As the answer to sustainability concerns, green economic growth has gradually attracted considerable attention. Notably, the optimization of the institutional environment contributes to green economic growth from the perspective of new institutional economics. However, few studies have systematically explained the connection between the institutional environment and green growth. In this study, the institutional environment was divided into three dimensions: governmental, legal, and cultural subenvironments. We adopted econometric models with the effect of every dimension on green growth and empirically analyzed with the generalized method of moments, based on Chinese provincial panel data from the years 2000-2016. The results indicated that there was an inverted U-shaped relationship between China's institutional environment and its green growth. That is, the institutional environment can initially promote China's green growth but, if it is not changed, will eventually inhibit it. In addition, the analysis on the three dimensions of the institutional environment highlighted that the role of the cultural subenvironment in green growth is greater than those of the governmental and legal subenvironments.

\section{Introduction}

Under the pressure of environmental pollution and the energy crisis, as well as through the pursuit of a highquality life for citizens, China has modified its environmental policies to allow for a transition from a brown economy of high consumption and emission to a green economy that is environmentally friendly. Green economy aims to change production and consumption by improving resource efficiency and reducing pollution emissions and hence promote harmony between the environment and the economy. Notably, China's total energy consumption reached 4.86 billion tons of standard coal in 2019, accounting for $24.3 \%$ of the world's total energy consumption. In particular, coal accounts for $57.7 \%$ of China's total energy consumption [1]. As China's economic growth slows down, it is trying to implement a green economic development model and fulfill international commitments, such as the Paris Agreement. China has suggested developing a green economy to release both energy and environmental pressures and has presented a series of policies to promote green economy transformation. For example, in 2016, The 13th Five-Year Plan for Economic and Social Development of the People's Republic of China introduced the green concept into the guidelines on building a moderately prosperous society in an all-round way. In 2017, the green economy concept became an important focus of China's national strategic plan. Finally, in 2018, the National Development and Reform Commission established the Green Industry Guide Directory. The new institutional economy proposes that "the institution is a new growth point of economy." From the perspective of this new institutional economy, the promotion of institutional quality can be beneficial for economic growth. In the context of this economic transformation, it is necessary to assess the effects of institutions on China's green economy.

In the past ten years, green economy, also known as green growth, has become a buzzword and has attracted great attention from the government, enterprises, researchers, and other stakeholders [2, 3]. Some studies have focused on the quality and measurement of green economy [4-7]. Furthermore, other studies have assessed the factors that affect green growth and have suggested that foreign 
direct investment (FDI), environmental regulations, financialization, and clean energy technologies are the most important ones [7-9].

The development of a new institutional economy has boosted research on institutional quality and institutional reform. For instance, a growing number of articles have suggested and constructed more effective indexes and methods to evaluate institutional quality. In addition, some articles have discussed the paths and characteristics of institutional evolution $[10,11]$. Nonetheless, over the last decade, researchers rarely have considered the factors that affect the institutional environment, such as capital flows, financial development, green innovation, and energy efficiency [12-14]. As for the relationship between institutional quality and economic growth, some studies have suggested it is robust and positive [15]. However, few studies have considered the multidimensional institutional environment and examined the effect of the institutional environment on green economy.

The present study examined the relationship between the multidimensional institutional environment and green economy. We empirically examined Chinese provincial data from the years 2000 to 2016. We divided the institutional environment into governmental, legal, and cultural subenvironments (GSE, LSE, and CSE, respectively) and estimated the specific effects of these subenvironments on the green growth in China. The results indicated an inverted " $U$ shaped" nonlinear relationship between the institutional environment and green growth, and the cultural subenvironment was more important than both the governmental and legal subenvironments.

Our study presents two main innovations. First, as the impact of the institutional environment on green growth is often ignored by developing countries, we utilized China as an example to conduct the investigation, which presents a new perspective for research that focuses on the institutional environment and green growth in developing countries. Second, the relative importance of the Chinese institutional environment and its subindicators for green growth was analyzed, which provides a reference for improving the institutional environment and promoting green growth in other countries.

Hereafter, we present a literature review and hypotheses (Section 2), describe the modeling process and data selection (Section 3), present and discuss regression results (Section 4 ), and provide recommendations for policymaking and future research (Section 5).

\section{Literature Review}

2.1. Green Growth. As a "triple-win" solution to sustainable development, green growth, which positively affects the economy, environment, and energy, attracts the attention of many researchers from different fields. Green growth, also referred to as green economy, has multiple definitions but, tracing back to its origins, green growth encompasses the concept of environmentally sustainable economic growth $[3,16,17]$. The World Bank describes green growth as "one that is efficient in its use of natural resources, clean in that it minimizes pollution and environmental impacts, and resilient in that it accounts for natural hazards" [18].

The measurement of green growth is divided into two categories: the indirect approach-such as the use of integrated indexes with weighting and aggregating techniques, as well as screening and comprehensive green economy indicators-and the direct approach, such as the application of the global Malmquist-Luenberger productivity index and super-efficiency DEA models [4, 5, 7]. However, researchers have gradually recognized methods based on more factors and comprehensive comparisons. Likewise, in the present study, we constructed a green productivity index with a super-efficiency DEA model to evaluate the development of green economy.

Multiple factors affect green growth, among which environmental regulations, fiscal expenditure, financialization, clean energy transition, economic openness, and research and development $(R \& D)$ investment have been discussed in recent years $[7,9,19,20]$. To date, a few studies have also investigated the relationship between institutional quality and economic growth [21, 22]. Salman et al. [22] have suggested that the quality of institutions is a factor that promotes economic growth, but Abdulahi et al. [21] have treated institutions as a threshold variable because institutional quality has a dynamic effect on economic growth. However, hardly any studies have focused on the effects of institutional quality on green economy, and the effects of governmental subenvironments on green economic growth have seldom been discussed. Therefore, the institutional environment and green growth were assessed in the present study.

2.2. Institutional Environment. Among the studies that discuss institutional quality and economic growth, many are indirect research. That is, the authors adopted an institutional environment as a control variable to analyze the effects of many variables, such as international aid, FDI, economic openness, resource endowment, and resource rents, on economic growth with different institutional qualities [21, 23-26]. Overall, these studies agree that a country with a good institutional environment is advantageous for economic subjects to absorb and use foreign aid, FDI, resource factors, and so on. Furthermore, improving institutional quality is advantageous to avoid resource curse [26] and promotes economic growth by affecting other factors [27].

Some studies have adopted institutional quality as a mediator and have analyzed its effects on economic growth. For example, Dong and Zhang [28] have argued that historically accumulated social capital promotes institutional quality and improves economic growth. Additionally, Berdiev et al. [29] have introduced an important institutional factor, namely, corruption, as a mediator to analyze the negative effects of racial inequality on economic growth. They have suggested that corruption induces about twothirds of the negative effects of racial inequality on economic growth.

By comprehensively reviewing previous literature, we discovered that empirical research on institutional quality has mainly concentrated on international comparisons and 
analyzed the effects of the institutional quality of a country on international capital and factor mobility, among others, on the economic growth of that country. In contrast, researchers rarely have empirically investigated institutional quality at the subnational level because of a lack of data. Therefore, in this article, it was meaningful to organize the path for the institutional environment that affects economic growth and evaluate the direct effects of institutional quality on economic growth within different dimensions.

\subsection{Multidimensional Institutional Environment and Green} Growth. According to the logistics of the new institutional economy, institutional quality has a direct effect on the strategies of investors and enterprises [30]. Furthermore, the investment directions and production decisions of firms directly affect green economy transformation. Only when the investment directions and production decisions become cleaner will green industries develop further and, in turn, transform faster into a green economy. In line with the statements in Section 2.1, we hereby discuss the effects of multidimensional institutional environments on green growth.

Regarding the relationship between the GSE and green growth, researchers have commonly suggested that the optimization of the institutional environment decreases transaction costs, promotes factor mobility to optimize resource allocations, reduces space for corruption and rentseeking, provides a fairer setting with a new significance for entrepreneurs, which inspires innovation, and further promotes development in different industries [31]. Whether the optimization of the GSE promotes green transformation also relies on the relative speed and weight of the development of green industries. In the context of "Chinese style decentralization," the development trends of local governments affect the impact of the GSE on green economic growth, to some extent. Under Chinese fiscal decentralization, the competition between local governments has been mentioned in many studies on political or institutional impacts $[32,33]$. The role of a local government as "an economic politician" prompts its motivation to develop the local economy and realize economic accumulation quickly. Notably, government behavior affects the governmental subenvironment to a great extent. If a local government is short-sighted and eager to realize economic catch-ups, the optimization of the institutional environment will provide a convenient and favorable development space for extensive industries but will restrict the development of green industries, all of which is not beneficial for the transformation to a green economy. However, if the local government fully realizes that the need for green economy transformations is urgent when targeting sustainable development, its GSE will tend to serve green industries, which is beneficial for green economic growth.

Considering the impacts of the LSE, a good legal environment leads to good investment expectations and, hence, attracts more investments to fuel local economic growth. Furthermore, the promotion of the rule of law is beneficial for protecting intellectual property rights, promoting the enthusiasm of entrepreneurs for innovation, increasing enterprise performance [32], and, finally, providing the possibility of developing a green economy. Moreover, a good legal environment provides a stable social environment for economic development, increases the cost of breaking contracts, allows more human resources to enter into social production, and promotes factor utilization. However, the impact of government behavior also needs to be considered when analyzing the impacts of the LSE owing to its lawmaking authority. That is, if the government behavior supports green transformations, then the legal environment will become conducive as well. If the government chooses a wild and unsustainable way to realize capital accumulations, the optimization of the legal environment will support the development of highly polluting industries. Therefore, the effect of the LSE on green growth is uncertain and influenced by the behavior of the local government.

Economists have suggested that informal regulations, such as culture, are significant determinants of economic performance [28]. For instance, a positive culture of business may be a major impetus for economic growth. Likewise, a positive culture of business for environmental protection may format the driving force behind green economy transformations. As a soft power, regional entrepreneurial spirit of innovation plays a positive leading role and generates an internal motivation for economic development. Overall, the use of soft power is sometimes better than that of coercion [34]. However, if entrepreneurs focus on making nongreen innovations in a relatively mature market to make quick profits, their behaviors may not be beneficial for the transformation to a green economy. Therefore, forming an environment that protects culture is a precondition for the positive impact of the CSE on green economy transformation.

Based on Figure 1, the following hypotheses were proposed.

Hypothesis 1. The optimization of the institutional environment has a positive effect on the transformation to a green economy.

Hypothesis 2. The subindicators of the institutional environment, such as the governmental, legal, and cultural subenvironments, have an impact on green growth.

To verify these hypotheses, we used Chinese data from the years 2000 to 2016 to analyze the impact of the institutional environment and its subindicators on green growth by establishing regression models.

\section{Model and Data}

3.1. Model. According to the analyses in the previous sections and considering the temporal spillover effect of development and technological progress [24,35], we adopted a model with the lag term of green total factor productivity (GTFP) to estimate the spillover effect of FDI on GTFP through the generalized method of moments (GMM). To do so, the following formula was used: 


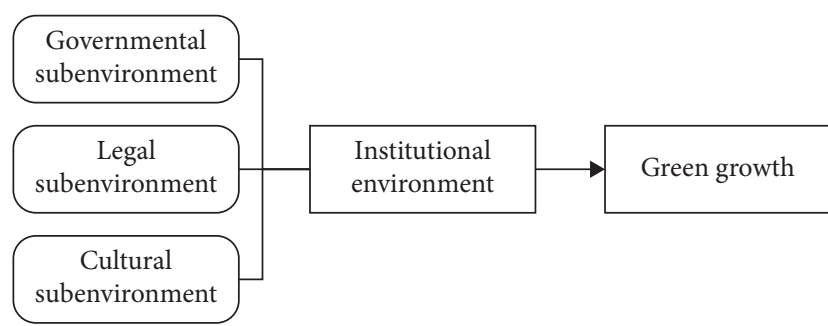

FIgURE 1: Framework of the concepts.

$$
\begin{aligned}
\mathrm{GTFP}_{i t}= & \alpha+\sigma \mathrm{GTFP}_{i, t-1}+\beta \operatorname{Insti}_{i t}+\delta_{j} \text { Control }_{i t} \\
& +\operatorname{region}_{i}+\text { year }_{t}+\varepsilon_{i t},
\end{aligned}
$$

where Insti $i_{i t}$ is the FDI inflow of region $i$ in the year $t$, Control $_{i t}$ represents control variables, region ${ }_{i}$ and year ${ }_{t}$ represent the individual effects and time effects, respectively, and $\varepsilon_{i t}$ is the standard error.

According to the previous theoretical analysis, institutional improvement may be affected by government behaviors. Considering its role as an "economic politician" and the time variance of its behaviors, a government dominates its competitive strategy with local resource endowment and a foreign competitive environment to form behavior trends in different orientations. Although the results of institutional improvement inevitably induce dynamic effects, it is difficult to weight government behaviors. In this study, we analyzed the nonlinear effects of institutional factors on green economic growth by modeling variables, including the institutional environment, in a quadratic term. Based on this, we constructed the following quadratic model:

$$
\mathrm{GTFP}_{i t}=\alpha+\sigma \mathrm{GTFP}_{i, t-1}+\beta \operatorname{Insti}_{i t}+\gamma \operatorname{Insti}_{i t}^{2}+\delta_{j} \operatorname{Control}_{i t}+\operatorname{region}_{i}+\text { year }_{t}+\varepsilon_{i t}
$$

To further analyze the impacts of institutional subenvironments of different dimensions on green growth, we introduced three institutional subenvironments into the models and constructed a basic model:

$$
\mathrm{GTFP}_{i t}=\alpha+\sigma \mathrm{GTFP}_{i, t-1}+\beta_{1} \mathrm{GSE}_{i t}+\beta_{2} \mathrm{LSE}_{i t}+\beta_{3} \mathrm{CSE}_{i t}+\delta_{j} \operatorname{Control}_{i t}+\operatorname{region}_{i}+\text { year }_{t}+\varepsilon_{i t},
$$

where $\mathrm{GSE}_{i t}, \mathrm{LSE}_{i t}$, and $\mathrm{CSE}_{i t}$ denote the governmental, legal, and cultural subenvironments, respectively.

Finally, we introduced the quadratic term of the three institutional subenvironments to identify the possible nonlinear relationships between these institutional subenvironments and green growth:

$$
\mathrm{GTFP}_{i t}=\alpha+\sigma \mathrm{GTFP}_{i, t-1}+\beta_{1} \mathrm{GSE}_{i t}+\beta_{2} \mathrm{LSE}_{i t}+\beta_{3} \mathrm{CSE}_{i t}+\gamma_{1} \mathrm{GSE}_{i t}^{2}+\gamma_{2} \mathrm{LSE}_{i t}^{2}+\gamma_{3} \mathrm{CSE}_{i t}^{2}+\delta_{j} \mathrm{Control}_{i t}+\operatorname{region}_{i}+\mathrm{year}_{t}+\varepsilon_{i t} .
$$

3.2. Data. According to the green growth statement of the World Bank and following [36], we included the GTFP, which was estimated with a super-efficiency DEA model, as an indicator of green growth. Herein, the detailed description of the DEA model has been omitted.

As the main explanatory variable, the institutional environment was measured based on the approach of [37]. Correspondingly, we assessed the GSE with five factors, including government domination, government interruption, tax on enterprises, and efficiency of administrative approval, evaluated the LSE with four factors, namely, anticorruption, social stability, patent protection, and labor protection, and identified the CSE mainly based on the entrepreneurial spirit of innovation. The description of these basic indexes is provided in Table 1. Due to insufficient data, the indexes of the institutional environments obtained in the present study differed slightly from the basic indexes proposed in [37]. Herein, details on the method have been omitted.
Based on previous studies, FDI, the level of education, and industrial structure and openness were selected as the control variables in the regressions described in Section 4 $[20,38]$. All the regression variables and their corresponding indexes are described in Table 2.

We employed the panel data of 30 provinces in mainland China from the years 2000-2016. Data were derived from multiple databases, including the China Statistical Yearbooks, China Population and Employment Statistics Yearbook, Procuratorial Yearbook of China, China Intellectual Property Yearbook, Yearbook of Industry and Commerce Administration of China, and China Labour Statistical Yearbook. The statistics for all related variables are summarized in Table 2. We evaluated the variance inflation factor (VIF) of each regression model, and the obtained VIF values were below 5 . Therefore, it can be considered that there was no multicollinearity. In addition, according to the Ramsey regression equation specification error test, the 
TABLE 1: Indexes of institutional environment quality.

\begin{tabular}{|c|c|c|c|}
\hline Variable & Basic index & Description & Direction \\
\hline Institutional quality & \multicolumn{2}{|c|}{$\begin{array}{l}\text { A comprehensive index constituted through the entropy weight method, based on three } \\
\text { subindexes-government, law, and culture }\end{array}$} & + \\
\hline \multirow{5}{*}{$\begin{array}{l}\text { Governmental } \\
\text { subenvironment }\end{array}$} & Government domination & Public finance expenditure/GDP & - \\
\hline & Government interruption & Local financial revenue/local financial expenditure & - \\
\hline & Scale of government & $\begin{array}{l}\text { Number of employees in public management and social organizations } \\
\text { at the end of the year/total population }\end{array}$ & - \\
\hline & Tax on enterprises & Industrial enterprise tax/operating revenue & - \\
\hline & $\begin{array}{l}\text { Efficiency of administrative } \\
\text { approval }\end{array}$ & $\begin{array}{l}\text { Administrative examination and approval procedures' concise } \\
\text { situation enterprise sampling rating }\end{array}$ & + \\
\hline \multirow{4}{*}{ Legal subenvironment } & Corruption & Number of graft cases/total population & - \\
\hline & Social stability & Logarithm of the number of criminal offenses per 10,000 people & - \\
\hline & Patent protection & Cumulative settlement of patents/cumulative number of filed patents & + \\
\hline & Labor protection & Labor dispute cases/total population & - \\
\hline $\begin{array}{l}\text { Cultural } \\
\text { subenvironment }\end{array}$ & $\begin{array}{l}\text { Innovation } \\
\text { entrepreneurship }\end{array}$ & Logarithm of (patent grants/total employed population $\times 10,000$ ) & + \\
\hline
\end{tabular}

Note. "+" means that the variable theoretically has a positive effect on the institutional quality, while “-” implies a negative one.

TABLE 2: Summary statistics.

\begin{tabular}{|c|c|c|c|c|c|c|}
\hline Variable & Description & Obs & Mean & Std. dev. & Min & Max \\
\hline GTFP & Green economic growth: total factor productivity & 510 & 0.4872 & 0.2214 & 0.1283 & 1.0000 \\
\hline INSTIL & Institutional quality & 510 & 5.9995 & 0.6528 & 4.2149 & 7.8347 \\
\hline GSE & Governmental subenvironment & 510 & 7.0041 & 0.7808 & 4.5242 & 8.4932 \\
\hline LSE & Legal subenvironment & 510 & 6.1017 & 0.5943 & 3.4581 & 8.5107 \\
\hline CSE & Cultural subenvironment & 510 & 4.8927 & 1.9576 & 0.0000 & 10.0000 \\
\hline FDI & Foreign direct investment: total utilized FDI/GDP & 510 & 0.0270 & 0.0295 & 0.0000 & 0.2074 \\
\hline EDU & $\begin{array}{c}\text { Education: weighted average valuation of classified and assigned different levels of } \\
\text { education }\end{array}$ & 510 & 8.4035 & 1.0559 & 5.4383 & 12.3891 \\
\hline MARKET & Marketization: marketization level & 510 & 6.0102 & 1.8 & 2.3700 & 10.9200 \\
\hline OPEN & Openness: total volume of foreign trade/GDP & 510 & 0.3415 & 0.4399 & 0.0133 & 1.8910 \\
\hline $\mathrm{RD}$ & The proportion of research and development expenditure in GDP & 510 & 0.0127 & 0.0104 & 0.0015 & 0.0628 \\
\hline URBAN & The proportion of urban population in total population & 510 & 0.4838 & 0.1538 & 0.1389 & 0.8961 \\
\hline IS & Industrial structure: the value of secondary industry output/GDP & 510 & 0.9386 & 0.4643 & 0.4945 & 4.1656 \\
\hline
\end{tabular}

quadratic term was reasonable. For variables involving prices, the base period was the year 2000. Furthermore, indicators involving exchange rates (e.g., FDI) were calculated according to the average exchange rate of each year.

\section{Regressions and Discussion}

Based on the aforementioned theoretical analysis, we constructed econometric models and selected the two-step estimation of the system GMM for regressions to deal with endogeneity problems. The estimation results of these models are shown in Table 3. Notably, we used a generalized least squares regression for Model 1 and did not incorporate the GTFP lag term into the model. We used a fixed effect regression for Model 2 and a GMM regression for Model 3. Finally, Models 4 and 5 included the quadratic term of institutional quality (INSTIL) to check the nonlinear relationship between INSTIL and GTFP. According to the results of the Sargan and AR tests, it was suitable to apply the GMM to estimate the relationship between institutional environment and economic growth. The following sections (i.e., Sections 4.1-4.3) explain and analyze the five models from the perspectives of both the total effects and effects of multidimensional institutions, based on Table 3 .
4.1. Effect of the Institutional Environment on Green Growth. The coefficient of the lag term of GTFP was positive and significant at the $1 \%$ level in all models (Table 3 ), which is consistent with the results in [7]. That is, green economic growth in a specific year had a positive influence on the growth in the following year. This phenomenon can be described as the lock-in effect on economic growth; Thus, this implies that a certain district should concentrate on the dependence effect on economic growth, except for spillover effects in the future.

In Model 1, the coefficient of the institutional environment was positive, but after introducing the quadratic term of institutions (i.e., in Models 4 and 5), the linear and quadratic terms of INSTIL became significantly positive and significantly negative, respectively. This means that the relationship between the institutional environment and green economic growth is characterized by an inverse $U$ shape. Accordingly, with institutional quality improvement, the effects of the institutional environment convert from improving positively to restraining green economic development, which is distinct with Hypothesis 1 to some extent. These unexpected results can be attributed to the control of government competition. In the context of the Chinese fiscal decentralization, the government plays the role of an 
TABLE 3: Effect of the institutional environment on green growth.

\begin{tabular}{|c|c|c|c|c|c|}
\hline GTFP & $\begin{array}{l}\text { Model } 1 \\
\text { GLS }\end{array}$ & $\begin{array}{c}\text { Model } 2 \\
\text { FE }\end{array}$ & $\begin{array}{l}\text { Model } 3 \\
\text { GMM }\end{array}$ & $\begin{array}{c}\text { Model } 4 \\
\text { FE }\end{array}$ & $\begin{array}{l}\text { Model } 5 \\
\text { GMM }\end{array}$ \\
\hline L. GTFP & & $\begin{array}{c}0.6320^{* * *} \\
(17.45)\end{array}$ & $\begin{array}{c}0.2933^{* * *} \\
(7.91)\end{array}$ & $\begin{array}{c}0.6534^{* * *} \\
(17.38)\end{array}$ & $\begin{array}{c}0.3405^{* * *} \\
(7.29)\end{array}$ \\
\hline INSTIL & $\begin{array}{c}0.0447^{*} \\
(1.90)\end{array}$ & $\begin{array}{c}0.0416^{* *} \\
(2.33)\end{array}$ & $\begin{array}{c}0.0737^{* * *} \\
(3.24)\end{array}$ & $\begin{array}{c}0.3364^{* *} \\
(2.30)\end{array}$ & $\begin{array}{c}1.0150^{* * * *} \\
(3.00)\end{array}$ \\
\hline INSTIL $^{2}$ & & & & $\begin{array}{c}-0.0245^{* *} \\
(-2.03)\end{array}$ & $\begin{array}{c}-0.0782^{* * *} \\
(-2.90)\end{array}$ \\
\hline FDI & $\begin{array}{c}0.2786 \\
(0.69)\end{array}$ & $\begin{array}{c}0.3199 \\
(1.05)\end{array}$ & $\begin{array}{c}-3.3433^{* *} \\
(-2.49)\end{array}$ & $\begin{array}{r}0.2761 \\
(0.90)\end{array}$ & $\begin{array}{c}-4.1805^{* *} \\
(-2.18)\end{array}$ \\
\hline EDU & $\begin{array}{c}-0.0004 \\
(-0.02)\end{array}$ & $\begin{array}{c}0.0518^{* * *} \\
(3.86)\end{array}$ & $\begin{array}{c}0.1207^{* * *} \\
(5.89)\end{array}$ & $\begin{array}{c}0.0472^{* * * *} \\
(3.48)\end{array}$ & $\begin{array}{c}0.1194^{* * *} \\
(5.42)\end{array}$ \\
\hline OPEN & $\begin{array}{c}-0.0980^{* *} \\
(-2.31)\end{array}$ & $\begin{array}{c}-0.0471 \\
(-1.27)\end{array}$ & $\begin{array}{c}0.0838 \\
(0.84)\end{array}$ & $\begin{array}{c}-0.0477 \\
(-1.29)\end{array}$ & $\begin{array}{c}0.0689 \\
(0.53)\end{array}$ \\
\hline MARKET & $\begin{array}{c}-0.0083 \\
(-0.94)\end{array}$ & $\begin{array}{c}-0.0081 \\
(-1.19)\end{array}$ & $\begin{array}{c}-0.0179^{* * *} \\
(-2.98)\end{array}$ & $\begin{array}{c}-0.0075 \\
(-1.09)\end{array}$ & $\begin{array}{c}-0.0173^{* *} \\
(-2.29)\end{array}$ \\
\hline $\mathrm{RD}$ & $\begin{array}{c}-0.4809 \\
(-0.21)\end{array}$ & $\begin{array}{c}-3.4976 \\
(-1.59)\end{array}$ & $\begin{array}{c}-10.6540^{* *} \\
(-2.51)\end{array}$ & $\begin{array}{c}-1.8456 \\
(-0.79)\end{array}$ & $\begin{array}{c}-7.8992^{*} \\
(-2.03)\end{array}$ \\
\hline URBAN & $\begin{array}{c}0.1376 \\
(1.62)\end{array}$ & $\begin{array}{c}0.0902 \\
(1.42)\end{array}$ & $\begin{array}{c}-0.5194^{* * *} \\
(-3.03)\end{array}$ & $\begin{array}{c}0.0823 \\
(1.30)\end{array}$ & $\begin{array}{c}-0.5229^{* *} \\
(-2.75)\end{array}$ \\
\hline IS & $\begin{array}{c}0.2277^{* * *} \\
(7.98)\end{array}$ & $\begin{array}{c}0.0818^{* * *} \\
(3.43)\end{array}$ & $\begin{array}{c}0.3239^{* * *} \\
(3.14)\end{array}$ & $\begin{array}{c}0.0743^{* * *} \\
(3.09)\end{array}$ & $\begin{array}{c}0.3147^{* *} \\
(2.47)\end{array}$ \\
\hline Constant & $\begin{array}{c}0.0238 \\
(0.18)\end{array}$ & $\begin{array}{c}-0.5248^{* * *} \\
(-5.28)\end{array}$ & $\begin{array}{c}-0.8919^{* * *} \\
(-3.84)\end{array}$ & $\begin{array}{c}-1.3847^{* * *} \\
(-3.18)\end{array}$ & $\begin{array}{c}-3.7132^{* * *} \\
(-3.74)\end{array}$ \\
\hline Observations & 510 & 480 & 480 & 480 & 480 \\
\hline Number of id & 30 & 30 & 30 & 30 & 30 \\
\hline R-squared & 0.548 & 0.579 & & 0.583 & \\
\hline $\mathrm{AR}(1)$ & & & $-2.38^{* *}$ & & $-2.73^{* * *}$ \\
\hline P-AR (1) & & & {$[0.017]$} & & {$[0.006]$} \\
\hline $\mathrm{AR}(2)$ & & & 0.02 & & -0.12 \\
\hline P-AR (2) & & & [0.983] & & {$[0.905]$} \\
\hline Hansen & & & 14.84 & & 15.93 \\
\hline P-Hansen & & & {$[0.463]$} & & [0.317] \\
\hline Hausman & 7.08 & 93.46 & & 124.38 & \\
\hline P-Hausman & {$[0.528]$} & {$[0.000]$} & & {$[0.000]$} & \\
\hline
\end{tabular}

Note. $t$-statistics are presented in parentheses; $p$ values are mentioned in brackets or indicated as ${ }^{* * *} p<0.01,{ }^{* *} p<0.05$, and ${ }^{*} p<0.01$; GLS: generalized least squares regression; FE: fixed effect regression; GMM: generalized method of moments.

economic politician and shows enthusiasm for developing the economy. In a situation where there is a lack of power for green transformations, improving institutional quality promotes a pollution economy and hinders its management. Hence, all the situations are not favorable for green economy transformations.

The analysis of control variables referred to the results of Models 3 and 5. Under the premise that endogeneity was controlled, the FDI coefficient was significantly negative, which indicates that there are issues with the structure of China's use of FDI. Therefore, China needs to optimize its FDI structure and introduce clean FDI to eliminate dirty FDI. However, the education (EDU) coefficient was significantly positive, which suggests that current human capital accumulation in China could positively affect green growth. As for the marketization level (MARKET), its negative value indicates that it cannot contribute to green transformations. Green growth needs to include both economic growth and environmental protection, and market failure is a factor that hampers effectively solving environmental problems. Finally, the industrial structure (IS) coefficient was significantly positive and differed from theoretical expectations. The main reason for this difference is that the green manufacturing industry has a positive impact on green economic growth within the green industry.

4.2. Effect of the Subenvironments on Green Growth. Following [37], we divided the institutional environment into three dimensions: the governmental, legal, and cultural subenvironments, and separately evaluated the effects of these subenvironments on green economic growth. We compared Models 1, 2, and 3 in Table 4 with the models that included quadratic terms, and the results suggest that for the models (Models 4, 5, and 6) that considered the quadratic terms of the GSE alone and those that gradually introduced quadratic terms, all regression coefficients were stable. This means that the regression results were robust, based on which we have obtained the model results described below.

The linear and quadratic coefficients of the GSE were significantly positive and significantly negative, respectively. There was a reverse U-shaped relationship between the GSE 
TABLE 4: Effect of the subenvironments on green growth.

\begin{tabular}{|c|c|c|c|c|c|c|}
\hline GTFP & $\begin{array}{l}\text { Model } 1 \\
\text { GMM }\end{array}$ & $\begin{array}{l}\text { Model } 2 \\
\text { GMM }\end{array}$ & $\begin{array}{l}\text { Model } 3 \\
\text { GMM }\end{array}$ & $\begin{array}{c}\text { Model } 4 \\
\text { GMM }\end{array}$ & $\begin{array}{c}\text { Model } 5 \\
\text { GMM }\end{array}$ & $\begin{array}{l}\text { Model } 6 \\
\text { GMM }\end{array}$ \\
\hline L. GTFP & $\begin{array}{l}0.0942 \\
(0.73)\end{array}$ & $\begin{array}{c}0.0390 \\
(0.51)\end{array}$ & $\begin{array}{c}0.6793 * * * \\
(5.13)\end{array}$ & $\begin{array}{c}0.5254 * * * \\
(4.28)\end{array}$ & $\begin{array}{c}0.4947 * * * \\
(7.20)\end{array}$ & $\begin{array}{c}0.4597 * * * \\
(4.09)\end{array}$ \\
\hline GSE & $\begin{array}{c}-0.1305 * * \\
(-2.45)\end{array}$ & & & $\begin{array}{c}1.6592 * \\
(1.89)\end{array}$ & & \\
\hline LSE & & $\begin{array}{c}0.0627 * \\
(1.92)\end{array}$ & & & $\begin{array}{c}0.2356 * * \\
(2.37)\end{array}$ & \\
\hline CSE & & & $\begin{array}{c}0.0449 * \\
(1.98)\end{array}$ & & & $\begin{array}{c}-0.1568 * * \\
(-2.63)\end{array}$ \\
\hline $\mathrm{GSE}^{2}$ & & & & $\begin{array}{c}-0.1257 * \\
(-2.03)\end{array}$ & & \\
\hline $\mathrm{LSE}^{2}$ & & & & & $\begin{array}{c}-0.0171 * * \\
(-2.11)\end{array}$ & \\
\hline $\mathrm{CSE}^{2}$ & & & & & & $\begin{array}{c}0.0211 * * * \\
(3.58)\end{array}$ \\
\hline FDI & $\begin{array}{c}-16.2412 * * \\
(-2.33)\end{array}$ & $\begin{array}{c}0.6968 \\
(0.39)\end{array}$ & $\begin{array}{c}-0.9655 \\
(-0.39)\end{array}$ & $\begin{array}{c}-0.7689 \\
(-0.40)\end{array}$ & $\begin{array}{c}-0.6856 \\
(-1.04)\end{array}$ & $\begin{array}{c}-0.9687 \\
(-0.39)\end{array}$ \\
\hline EDU & $\begin{array}{c}0.1247 * \\
(2.00)\end{array}$ & $\begin{array}{c}0.1319 * * * \\
(3.49)\end{array}$ & $\begin{array}{c}0.0332 \\
(1.24)\end{array}$ & $\begin{array}{c}0.0065 \\
(0.22)\end{array}$ & $\begin{array}{c}0.0752 * * * \\
(5.22)\end{array}$ & $\begin{array}{c}0.0545 \\
(1.39)\end{array}$ \\
\hline OPEN & $\begin{array}{c}1.1243 * * \\
(2.34)\end{array}$ & $\begin{array}{l}0.1264 \\
(0.77)\end{array}$ & $\begin{array}{c}-0.0089 \\
(-0.06)\end{array}$ & $\begin{array}{l}0.1045 \\
(0.71)\end{array}$ & $\begin{array}{c}0.0066 \\
(0.11)\end{array}$ & $\begin{array}{c}-0.2137 \\
(-1.44)\end{array}$ \\
\hline MARKET & $\begin{array}{c}-0.0260 \\
(-1.23)\end{array}$ & $\begin{array}{c}-0.0476 * * * \\
(-3.15)\end{array}$ & $\begin{array}{c}-0.0024 \\
(-0.21)\end{array}$ & $\begin{array}{l}0.0140 \\
(0.75)\end{array}$ & $\begin{array}{c}-0.0092 \\
(-1.33)\end{array}$ & $\begin{array}{c}-0.0567 * * * \\
(-3.21)\end{array}$ \\
\hline $\mathrm{RD}$ & $\begin{array}{c}-37.6598 * \\
(-1.96)\end{array}$ & $\begin{array}{c}-1.1538 \\
(-0.13)\end{array}$ & $\begin{array}{c}-7.6374 \\
(-0.76)\end{array}$ & $\begin{array}{c}-12.0741 \\
(-1.25)\end{array}$ & $\begin{array}{c}-8.8985 * \\
(-1.93)\end{array}$ & $\begin{array}{l}1.2157 \\
(0.14)\end{array}$ \\
\hline URBAN & $\begin{array}{c}-0.8960 \\
(-1.49)\end{array}$ & $\begin{array}{l}0.2411 \\
(0.77)\end{array}$ & $\begin{array}{l}-0.3852 \\
(-0.75)\end{array}$ & $\begin{array}{l}0.1973 \\
(0.74)\end{array}$ & $\begin{array}{c}-0.0657 \\
(-0.61)\end{array}$ & $\begin{array}{c}-0.0799 \\
(-0.53)\end{array}$ \\
\hline IS & $\begin{array}{c}1.0922 * * * \\
(2.86)\end{array}$ & $\begin{array}{c}0.3489 * * \\
(2.70)\end{array}$ & $\begin{array}{c}0.1605 * \\
(1.78)\end{array}$ & $\begin{array}{c}0.2450 \\
(1.67)\end{array}$ & $\begin{array}{c}0.3754 * * * \\
(4.04)\end{array}$ & $\begin{array}{c}-0.1896 \\
(-1.23)\end{array}$ \\
\hline Constant & $\begin{array}{c}0.5281 \\
(0.68)\end{array}$ & $\begin{array}{c}-1.2660 * * * \\
(-2.82)\end{array}$ & $\begin{array}{l}-0.1792 \\
(-0.98)\end{array}$ & $\begin{array}{c}-5.4638 * \\
(-1.73)\end{array}$ & $\begin{array}{c}-1.3280 * * * \\
(-3.88)\end{array}$ & $\begin{array}{c}0.6346 * * \\
(2.39)\end{array}$ \\
\hline Observations & 480 & 480 & 480 & 480 & 480 & 480 \\
\hline Number of id & 30 & 30 & 30 & 30 & 30 & 30 \\
\hline $\begin{array}{l}\operatorname{AR}(1) \\
\operatorname{P-AR}(1)\end{array}$ & $\begin{array}{c}-2.222 * * \\
{[0.026]}\end{array}$ & $\begin{array}{c}-2.902 * * * \\
{[0.004]}\end{array}$ & $\begin{array}{c}-2.420 * * \\
{[0.016]}\end{array}$ & $\begin{array}{c}-2.562 * * \\
{[0.010]}\end{array}$ & $\begin{array}{c}-2.454 * * \\
{[0.014]}\end{array}$ & $\begin{array}{c}-2.211 * * \\
{[0.027]}\end{array}$ \\
\hline $\operatorname{AR}(2)$ & $\begin{array}{l}{[0.026]} \\
-0.299\end{array}$ & $\begin{array}{r}{[0.004]} \\
-0.569\end{array}$ & $\begin{array}{c}{[0.016]} \\
0.883\end{array}$ & $\begin{array}{c}{[0.010]} \\
1.562\end{array}$ & $\begin{array}{c}{[0.014]} \\
1.084\end{array}$ & $\begin{array}{l}{[0.02 /]} \\
-0.582\end{array}$ \\
\hline P-AR (2) & {$[0.765]$} & {$[0.569]$} & {$[0.377]$} & {$[0.118]$} & {$[0.278]$} & {$[0.561]$} \\
\hline Hansen & 9.931 & 13.67 & 7.317 & 4.554 & 14.04 & 9.899 \\
\hline P-hansen & {$[0.356]$} & {$[0.135]$} & {$[0.292]$} & {$[0.473]$} & {$[0.447]$} & {$[0.272]$} \\
\hline
\end{tabular}

Note. $t$-statistics are presented in parentheses; $p$ values are displayed in brackets or indicated as $* * *, p<0.01, * *, p<0.05$, and $*, p<0.01$; GMM: generalized method of moments.

and green growth in China, and its inflection point was at 6.5998. Notably, this result is consistent with the effect of the entire institutional environment. In contrast to the scores of the GSEs of different Chinese provinces in 2018, almost all provinces were listed on the left side of the inflection point and were in the process of promoting green economic growth. This means that the improvement of the current GSE could serve as a green transformation, and it also indicates that the effects of institutional environment optimization have not been consumed by the competition between local governments.

The linear coefficient of LSE was significantly positive, whereas the quadratic coefficient was significantly negative, which indicates that a reverse $\mathrm{U}$-shaped relationship exists between the LSE and green growth in China, with an inflection point at 6.8889 . In contrast with the scores of the LSE in each city and province for the test period, the LSE in most provinces was on the left side of the inflection point, which implies that the LSE is beneficial for green growth in the majority of Chinese districts. A possible explanation is that good opportunities for investments and productions, brought about by the optimization of the LSE, rapidly reflect on the traditional industries of mature markets and high technologies. As soon as the optimization of the LSE exceeds the inflection point, it will promote the development of the green industry and, finally, promote green economic growth. Therefore, the Chinese government should continue optimizing the LSE to reach the inflection point.

Finally, the linear coefficient of the CSE was negative, while the quadratic one was positive, highlighting the existence of a U-shaped relationship existing between the CSE and green growth in China, with an inflection point at 3.7156. Most regions were on the right side of the inflection point, which suggests that the improvement of the CSE 
Table 5: Dominance statistics.

\begin{tabular}{|c|c|c|c|c|c|c|}
\hline \multirow{2}{*}{ GTFP } & \multicolumn{2}{|c|}{ Model 1} & \multicolumn{2}{|c|}{ Model 2} & \multicolumn{2}{|c|}{ Model 3} \\
\hline & Domin. & Rank & Domin. & Rank & Domin. (\%) & Rank \\
\hline INSTIL & 13.41 & 3 & & & & \\
\hline GSE & & & 10.17 & 2 & 3.28 & 9 \\
\hline LSE & & & 7.76 & 3 & 5.43 & 7 \\
\hline CSE & & & 82.07 & 1 & 9.20 & 3 \\
\hline FDI & 8.08 & 4 & & & 6.84 & 5 \\
\hline EDU & 5.57 & 6 & & & 5.48 & 6 \\
\hline OPEN & 5.36 & 7 & & & 4.01 & 8 \\
\hline MARKET & 22.21 & 2 & & & 23.80 & 2 \\
\hline $\mathrm{RD}$ & 8.01 & 5 & & & 7.24 & 4 \\
\hline URBAN & 2.97 & 8 & & & 2.43 & 10 \\
\hline IS & 34.39 & 1 & & & 32.30 & 1 \\
\hline
\end{tabular}

significantly can promote China's green growth. This demonstrates that we should strengthen $\mathrm{R} \& \mathrm{D}$ on green patents to promote green transformations with environmentally friendly technological innovations.

4.3. Relative Importance Analysis. The aforementioned results show that the institutional environment has a significant impact on China's green growth, but the main goal of the present study was to assess the contribution of the institutional environment relative to other factors. Therefore, a relative importance (RI) analysis was conducted. This analysis determines the relative importance of independent variables in an estimation model based on their contribution to an overall model fit statistic. We used the methods of $[39,40]$ to standardize the values of RI [41]. The results are shown in Table 5.

In Model 1, the influence of INSTIL on China's green growth ranked third, with a dominance of $13.41 \%$. IS and MARKET ranked first and second, respectively, accounting for more than $50 \%$ of the total dominance in Model 1, and hence are the most important driving factors for China's green growth. Although the dominance of the institutional environment was lower than that of the other two variables, its effect on green growth cannot be ignored.

Model 2 and model 3 consider the impact of different dimensions of institutional environment on green growth. Notably, the relative importance of the CSE within the three subenvironments exceeded the sum of that of GSE and LSE. After adding the control variables, CSE ranked third, and the dominance of GSE and LSE was surpassed by R\&D, FDI, and EDU. This means that the cultural system has played an important role in China's current green growth, but improvement is needed in its legal system and governance capabilities.

\section{Conclusions}

The present study has highlighted that there is an inverted U-shaped nonlinear relationship between China's overall institutional environment and green growth. The institutional environment can significantly improve green growth at the initial stage of economic development, but, as the economy continues to develop, the institutional environment will hinder green growth. Notably, different dimensions of the institutional environment have distinct impacts on green growth. According to the analysis of relative importance, the cultural subenvironment is more important than both the governmental and the legal ones.

Enhancing the positive role of the institutional environment on green growth while overcoming its negative role is an important issue that China needs to solve. Based on the aforementioned results, we hereby provide policy guidelines for governments.

(1) Emphasizing guidance on the effects of institutional efficiency and prioritizing services for green industry growth is crucial. The transformation of service effectiveness as a result of the promotion of institutional efficiency is greatly affected by government behavior. Therefore, for the governmental subenvironment to play a positive role in green growth, the government should prioritize green industries and further transform the governmental subenvironment into service for green transformation.

(2) Efforts should be directed towards improving the rules of law and strengthening the optimization of the legal subenvironment. For instance, the current Chinese law system has not reached the inflection point yet, which means it still is suboptimal and could not improve green economic growth. Therefore, the government needs to gradually improve the law system, increase the efficiency of laws and regulations, ensure that law enforcement is strict and law breakers are handled accordingly, and construct a fair and safe environment to promote innovations, especially green ones, to a higher degree.

(3) There must be a focus on emphasizing the promotion of and education on public environmental protection to support the formation of a green growth concept. As a part of a country's soft power, culture is important and significant for economic growth. However, the cultural subenvironment could not positively affect green economic growth. It is a weakness that should be addressed, but it also represents an opportunity for the country. The 
government should strengthen the promotion of and education on environmental protection before forming a green growth culture. The effect of cultural methods on green innovations can eliminate its reliance on paths. Therefore, future system optimization processes should concentrate on the promotion of and education on environmental culture to form a common green growth idea, which would further be beneficial for the green transformations of the Chinese economy.

Although the GMM estimation and relative importance analysis are used to obtain consistent estimation results, the aspects described hereafter still need to be addressed in future studies. First, the mechanism of the impact of the institutional environment on green growth should be further evaluated. The institutional environment does not only directly affect green growth but also has intermediary or mediating effects, such as industrial upgrading, financial performance, and government organizations. Second, research at the microlevel should be promoted. Although an increasing number of studies have focused on the microimpact of institutions on economic activities, they have concentrated on a single dimension, such as government enterprise collusion, political uncertainty, or CEO background characteristics. Therefore, a comprehensive analysis of the institutional environment is still lacking.

\section{Data Availability}

The data used to support the findings of this study are available from the corresponding author upon request.

\section{Conflicts of Interest}

The authors declare that they have no conflicts of interest.

\section{Acknowledgments}

This study was supported by the National Natural Science Foundation of China (grant no. 71804001) and the Planning Project of Philosophy and Social Science Research in Anhui Province (grant no. AHSKQ2017D03).

\section{References}

[1] BP, Statistical Review of World Energy, British Petroleum Company, London, UK, 2020, https://www.bp.com/.

[2] E. Loiseau, L. Saikku, R. Antikainen et al., "Green economy and related concepts: an overview," Journal of Cleaner Production, vol. 139, pp. 361-371, 2016.

[3] A. Merino-Saum, J. Clement, R. Wyss et al., "Unpacking the Green Economy concept: a quantitative analysis of 140 definitions," Journal of Cleaner Production, vol. 242, Article ID 118339, 2020

[4] A. Merino-Saum, M. G. Baldi, I. Gunderson, and B. Oberle, "Articulating natural resources and sustainable development goals through green economy indicators: a systematic analysis," Resources, Conservation and Recycling, vol. 139, pp. 90-103, 2018.
[5] W. Pan, W. Pan, C. Hu et al., "Assessing the green economy in China: an improved framework," Journal of Cleaner Production, vol. 209, pp. 680-691, 2019.

[6] X. Pan, B. Ai, C. Li, X. Pan, and Y. Yan, "Dynamic relationship among environmental regulation, technological innovation and energy efficiency based on large scale provincial panel data in China," Technological Forecasting and Social Change, vol. 144, pp. 428-435, 2019.

[7] S. Shuai and Z. Fan, "Modeling the role of environmental regulations in regional green economy efficiency of China: empirical evidence from super efficiency DEA-Tobit model," Journal of Environmental Management, vol. 261, Article ID 110227, 2020.

[8] E. Hille, M. Shahbaz, and I. Moosa, "The impact of FDI on regional air pollution in the Republic of Korea: a way ahead to achieve the green growth strategy?" Energy Economics, vol. 81, pp. 308-326, 2019.

[9] S. Knuth, "“Breakthroughs” for a green economy? Financialization and clean energy transition," Energy Research \& Social Science, vol. 41, pp. 220-229, 2018.

[10] E. Brousseau and E. Raynaud, "Climbing the hierarchical ladders of rules": a life-cycle theory of institutional evolution," Journal of Economic Behavior \& Organization, vol. 79, no. 1-2, pp. 65-79, 2011.

[11] B. Neyapti and Y. Arasil, "The nexus of economic and institutional evolution," Economic Modelling, vol. 52, pp. 574582, 2016.

[12] E. Challe, J. I. Lopez, and E. Mengus, "Institutional quality and capital inflows: theory and evidence," Journal of International Money and Finance, vol. 96, pp. 168-191, 2019.

[13] M. A. Khan, M. A. Khan, M. E. Abdulahi, I. Liaqat, and S. S. H. Shah, "Institutional quality and financial development: the United States perspective," Journal of Multinational Financial Management, vol. 49, pp. 67-80, 2019.

[14] H. Sun, B. K. Edziah, C. Sun et al., "Institutional quality, green innovation and energy efficiency," Energy Policy, vol. 135, Article ID 111002, 2019.

[15] A. T. Young and K. M. Sheehan, "Foreign aid, institutional quality, and growth," European Journal of Political Economy, vol. 36, pp. 195-208, 2014.

[16] C. Wang, Q. Zhang, and W. Zhang, "Corporate social responsibility, Green supply chain management and firm performance: the moderating role of big-data analytics capability," Research in Transportation Business \& Management, vol. 37, p. 100557, 2020.

[17] X. Wang and Q. Shao, "Non-linear effects of heterogeneous environmental regulations on green growth in G20 countries: evidence from panel threshold regression," Science of the Total Environment, vol. 660, pp. 1346-1354, 2019.

[18] W. Bank, Inclusive Green Growth: The Pathway to Sustainable Development, World Bank Publications, Washington, DC, USA, 2012.

[19] B. Lin and J. Zhu, "Fiscal spending and green economic growth: evidence from China," Energy Economics, vol. 83, pp. 264-271, 2019.

[20] X. Song, Y. Zhou, and W. Jia, "How do economic openness and R\&D investment affect green economic growth?-evidence from China," Resources, Conservation and Recycling, vol. 146, pp. 405-415, 2019.

[21] M. E. Abdulahi, Y. Shu, and M. A. Khan, "Resource rents, economic growth, and the role of institutional quality: a panel threshold analysis," Resources Policy, vol. 61, pp. 293-303, 2019. 
[22] M. Salman, X. Long, L. Dauda, and C. N. Mensah, "The impact of institutional quality on economic growth and carbon emissions: evidence from Indonesia, South Korea and Thailand," Journal of Cleaner Production, vol. 241, pp. 118331118315, 2019.

[23] B. G. Buchanan, Q. V. Le, and M. Rishi, "Foreign direct investment and institutional quality: some empirical evidence," International Review of Financial Analysis, vol. 21, pp. 81-89, 2012.

[24] N. P. Canh, C. Schinckus, and S. D. Thanh, "Do economic openness and institutional quality influence patents? Evidence from GMM systems estimates," International Economics, vol. 157, pp. 134-169, 2019.

[25] A. A. Maruta, R. Banerjee, and T. Cavoli, "Foreign aid, institutional quality and economic growth: evidence from the developing world," Economic Modelling, vol. 89, 2019.

[26] Q. Qiang and C. Jian, "Natural resource endowment, institutional quality and China's regional economic growth," Resources Policy, vol. 66, Article ID 101644, 2020.

[27] W. Zhang, M. Zhang, W. Zhang, Q. Zhou, and X. Zhang, "What influences the effectiveness of green logistics policies? A grounded theory analysis," Science of the Total Environment, vol. 714, p. 136731, 2020.

[28] Z. Dong and Y. Zhang, "Accumulated social capital, institutional quality, and economic performance: evidence from China," Economic Systems, vol. 40, no. 2, pp. 206-219, 2016.

[29] A. N. Berdiev, J. W. Saunoris, and O. T. Coomes, "The path from ethnic inequality to development: the intermediary role of institutional quality," World Development, vol. 130, 2020.

[30] D. C. North and R. P. Thomas, The Rise of the Western World: A New Economic History, Vol. 171, Cambridge University Press, New York, NY, USA, 1973.

[31] J. He, M. Nazari, Y. Zhang et al., "Opportunity-based entrepreneurship and environmental quality of sustainable development: a resource and institutional perspective," Journal of Cleaner Production, vol. 256, Article ID 120390, 2020.

[32] W. He, L. Tan, J. Liu et al., "Property rights protection, environmental regulation and corporate financial performance: revisiting the Porter Hypothesis," Journal of Cleaner Production, vol. 264, Article ID 121615, 2020.

[33] K. Zhang, D. Xu, S. Li et al., "Strategic interactions in environmental regulation enforcement: evidence from Chinese cities," Environmental Science and Pollution Research, vol. 28, no. 2, 2021.

[34] R.-H. Xie, Y.-J. Yuan, and J.-J. Huang, "Different types of environmental regulations and heterogeneous influence on "green" productivity: evidence from China," Ecological Economics, vol. 132, pp. 104-112, 2017.

[35] Z. Yang, S. Shao, L. Yang, and J. Liu, "Differentiated effects of diversified technological sources on energy-saving technological progress: empirical evidence from China's industrial sectors," Renewable and Sustainable Energy Reviews, vol. 72, pp. 1379-1388, 2017.

[36] X. Zhou and C. Feng, "The impact of environmental regulation on fossil energy consumption in China: direct and indirect effects," Journal of Cleaner Production, vol. 142, pp. 3174-3183, 2017.

[37] H. Xu and T. Feng, "Does the optimization of institutional environment help to promote technological innovation? empirical analysis based on China's provincial dynamic space panels," Journal of Finance and Economics (In Chinese), vol. 44, pp. 47-61, 2018.
[38] B. Muhammad and S. Khan, "Effect of bilateral FDI, energy consumption, $\mathrm{CO} 2$ emission and capital on economic growth of Asia countries," Energy Reports, vol. 5, pp. 1305-1315, 2019.

[39] D. Krasikova, J. M. Lebreton, and S. Tonidandel, Estimating the Relative Importance of Variables in Multiple Regression Models, John Wiley \& Sons, Hoboken, NJ, USA, 2011.

[40] S. Tonidandel and J. M. Lebreton, "Relative importance analysis: a useful supplement to regression analysis," Journal of Business and Psychology, vol. 26, no. 1, pp. 1-9, 2011.

[41] D. Ye, Y.-K. Ng, and Y. Lian, "Culture and happiness," Social Indicators Research, vol. 123, no. 2, pp. 519-547, 2015. 